\title{
An Investigation on Factors that Influence the Customer Decision Making to Attend Sport Event and Product Differentiation Strategies Employed by Event Organizers
}

\author{
WMRK Weerakoon* \\ Department of Sport Science and Physical Education, Faculty of Social Sciences, University of Kelaniya, Sri Lanka
}

Submission: March 12, 2018; Published: March23, 2018

*Corresponding author: WMRK Weerakoon, Department of Sport Science and Physical Education, Faculty of Social Sciences, University of Kelaniya, Sri Lanka, Email: ranjan@kln.ac.lk

\begin{abstract}
Product differentiation is a unique marketing strategy for attracting consumers to a particular product. Therefore, managers are promoting a special characteristic of their product. The Sport products are deferent from other consumer products and it has special features. Therefore, the purpose of this study in general terms, is to explore the unique selling points of sporting events. Also, this study investigates, as a research problem, what unique selling points influence the sport spectators' decision to attend a sport event as well as what unique selling points used by sport event organizers differentiate their sport events. The study was consistent with both qualitative and quantitative research approached and was adapted to a purposive sampling method for collecting data. Structured questionnaires and semi- structured interviews were used for collecting data from a sample of University students at Northumbria University; to take part in the study, the participants had to be level six sport management students. The study used statistical tools such as T-test, and correlation for quantitative data analysis and thematic analysis used for qualitative data analysis. Results show that the age of the sport spectators does not render the event atmosphere significantly deferent, it means that the unique selling point of atmosphere holds equal importance for all age levels according to their purpose. Thus, the event profile, core product and hosing facility are very important factors for deciding whether or not to attend a sport event. In addition, in the sport organizers' point of view, the event atmosphere is their unique selling point for differentiating an event. And the core product has been used as their event differentiating strategy. Furthermore, researchers suggest that future studies could be done using deferent sample and unique selling point to measure the perception of spectators' decision to attend a sport event.
\end{abstract}

Keywords: Event Management; Unique selling point; Marketing Strategy

\section{Introduction}

In marketing and sport marketing fields, researchers have drawn attention to the product differentiation over the years [18]. Product differentiation is a marketing strategy which is used to attract and influence the customers on a product's unique values whereby overcoming competitive advantages among similar products. Especially, product differentiation creates greater values in the customer's mind when its attributes can be compared as more favorable than those associated with other products, using that strategy managers protect the demand of a product. Alpert [7] claims that a product's salient characteristics are derived in consumer minds which may be based on their personal motives; customers often mentally process the products' attributes in terms of their personal goals by associating personal values with product benefits before consumption. According to those explanations of product differentiation given by various researchers, it can be differentiated by packaging, distribution difference, and prestige of trademark, price, quality and trade name. In general, product differentiation genuinely responds to the customer needs, however sometimes it is artificially done by using marketing strategies.

In the last few decades, sport marketers and sport managers have dedicated time and effort to exaggerate factors that facilitated and promoted sport consumption. In particular, researchers have drowned their attention in variables that influence the direct sport consumption in the form of attendance at the sport event, while others have examined the effective factors or strategies that influence in attracting and participating or socio-psychological characteristics that influence in attending a sport event [9-14]. For instance, research indicates that weather and parking, ticket cost, promotional event, income, population size, team success, the presence of star players, personal involvement, Atmosphere, satisfaction, facility, Core 
product event profiles, added values and accessibility all play a significant role in sport consumption decisions [15-34]. And on other hand sport event organizers should take those factors into account for selecting unique selling points for differentiation of their sporting events.

Some factors were found to be of particular importance for the customers' decision to attend a sport event such as personal involvement, atmosphere, facility, core product, event profiles, cost and added values which represent other factors that affect the consumer decision. For instance, researcher Biscaia et al. [26] define that the core product is a sport event providing entertainment of competition based on uncertainty of the game outcome or physical goods/services association with the instigation of the sporting event. If event organizers are catering high quality goods or serves, it leads to; satisfaction, retaining their customers, generating long term benefits and surviving in the competitive market. In sport context, spectators' satisfaction is the most important factor for increasing the attendance of an event and revenues and from a managerial standing point, service quality is difficult to be controlled by event marketers that relates to stadium issues such as design, space, safety and atmospherics, supportive services, parking and accessibility [31]. Those are important factors for ensuring service quality of an event [35]. In addition, Ferreira [36] noted that core event factors that positively influence the students' decision to attend a college sporting event.

Furthermore, facility factors improve peripheral services of an event such as access, seat comfort, and cleanliness of the toilets, responsiveness of employees, facility space, layout, information signs, facility for children, and availability of food and drink which influence in creating an attractive game atmosphere, thus there are numerous ancillary service at a sport event including security, promotional activities, fun environment. Also, the attractiveness of team colors and logo helps to increase quality of facility and atmosphere. As Matsuoka et al. [24], Biscaia et al. [26], Yassim [33] and other researchers have indicated, those factors of facility and atmosphere have led to customer satisfaction, that has a strong link with the intention to attend future sport events and recommendation of attending others [37-39]. Moreover, Speed [40] reported that personal involvement of an event affects consumers in deciding to attend an event which means the event should be attached to some social values (Charity event) and communicate them to consumers' mind for identifying through their self-expression about the event. Filo et al. [6] notes that this enhances the spectators' motivation and recommendation to others to attend a charity sport event due to their feeling of personal involvement by the social values that are included in the event.

Added values factor is another considerable matter for sport consumers to make the decision of attending a sport event. Yassim [33] clearly argue that incentive (special ticket with meal in the concession area), discount (ticket for family or group) seasonal ticket, inducement and other promotional activities (display the lyric of club's anthem or family song) are spotlights for spectators to gain different experiences from the event, which motivate them to attending future events. In addition, event profile is another influencing factor for the decision to attend an event. The literature identified that general motivation factors for spectators to attend an event are: festival, rituals, atmosphere, patriotism and nationalism etc, apart from that especially, it has the influence of event profiles such as the scale of the event, global attraction, international dimension of game and opportunity for seeing sports legends. For instance, people attend the Olympic game for the sake of a once-in-a-life-time opportunity.

In conclusion, understanding the factors that influence the sport consumers' decision to attend sport events is fundamental to understanding sport consumption decision patterns. Previous research has explained the consumers' decision as a binary process, with the choice between either attending or not attending a particular sport event. Therefore, it is unclear what factors determine the consumers' decision regarding choice among different sport event alternatives and also in a managerial perspective, insight of consumes' decision making process and factors that determine the customers' choice are both important for product differentiation in a competitive market. However, there is limited research on unique selling points that have affected the decision of a university student to attend a sport event. Therefore, this study investigates as a research problem, what unique selling points influence university students' decision to attend a sport event as well as what unique selling points is used by sport event organizers that differentiate their sport event. As unique selling points of core event factors, facility, personal involvement, added values, cost, event profiles, and atmosphere would be examined in this study.

\section{Methodology}

This research study is based on deductive research approached and based on primary sources of data, which were collected by using mixed method, qualitative and quantitative data. The mixed method is used here in order to have a better understanding and for providing a reliable investigation for the research problem. Structured questionnaires and semistructured interviews were used for collecting data from a sample of University students at Northumbria University; to take part in the study, the participants had to be level six sport management students.

The quaternaries were consisted of three parts; the first part was covered by the bio-data of the participant; the second part was dedicated to core event factors which were collected data regarding experience of the last attended sport event, while the third part determined the service quality of the event in relation to the decision of either attending or not attending the sport event. The practical investigation of this study employed and collected forty-seven questioners from the level six students 
in the sport management degree programmed. This included 36 male and 11 female students. All these quaternaries were statistically analyzed according to the research purpose by using SPSS 21.0 software. To measure core event factors and service quality in relation to unique selling points that influence on the decision to attend a sport event in a consumer perspective, the questioner was adapted to a few research articles, which included 45 items of questions that represented six dimensions under the two major parts such as core event factors and services quality [41-47]. The six dimensions are personal involvement, cost of event, facility, event profiles, atmosphere and added values. The Likert type scale was used to obtain a response from the questioner excluding bio-data of the respondent. In the first part, responses were instructed to indicate importance of each item using a five-point scale ranging from 'no importance' (1) to 'high importance' (5) [10]. The second part was ranging from 'no influence (1) to 'high influence' (5). This study selected the non-probability sampling technique for collecting data from participants and the initial questioner was reviewed by the research process module tutor of MSc sport management degree programme at Northumbria University, if the questionnaire effectively measured the selected topic.

\section{Results and Discussion}

\section{Results}

The purpose of this study was to explore unique selling points of sporting events. The present study is two-fold and seeks to explore and identify the factors, from a consumer perspective that influence the decision making process that they go through when choosing to attend sporting events. This study was also exploring the differentiation of strategies implemented to attract consumers, from an event organizer's perspective.

For understanding the first part of the research purpose, three hypotheses were constructed; to test if there was a significant difference in perceptions of game atmosphere between ages 18-20 and 21-23, an independent t-test was carried out. There was NO significant difference between the scores of age 18-20 $(M=3.85, S D=.51)$ and age 21-23 $(M=3.94, S D=.69), t(39)=$ $-.48, p=.62$. Therefore, ages between 18-20 do not consider the importance of the atmosphere differently from ages 21-23 when considering the unique selling points of the event.

To test if there was a significant difference between the event profile and the facility hosting the event when deciding to attend an event, a paired samples t-test was carried out. There was a significant difference between the influence of event profile $(M=3.6, S D=.61)$ and the facility hosting the event $(M=3.4$, $S D=.58), t(46)=2.42, p<.005$. Therefore, the event profile is more important when deciding whether to attend an event. And to test if there is a significant relationship between how an individual importance of core product and the facility hosting an event when determining whether or not to attend an event, a Pearson correlation test was carried out. There was a positive significant correlation between the core product and facility ( $\mathrm{r}$ $=.68, p<.01$ ). Therefore, the core product and the facility have positively influenced people's decision on attending a sport event. For complete SPSS statistical analysis refer Appendix II.

In addition, for investigating the second part of the research purpose, qualitative data was gathered by five semi- structure interviews. The results show that event organisers basically took into account seven unique selling points to differentiate their sport event; Price, location, added values, event profiles, atmosphere, core product and personal Involvement. Event organisers have given weight to those unique selling points according to their purpose. All event organisers have used atmosphere to differentiate their event, who have tried to create a fun atmosphere. For instance, when asked "what kind of atmosphere do you want from this event?" from participants, "mainly fun and enjoyable", $p 5$, "we want it to be fun and enjoyable", p4, "A fun atmosphere, not too serious an event," p3 (Appendix III). And also every organiser had expected to differentiate their event through the factor of added values, for example, $p 1$; "if people dress up like with themes", "he will get a T-shirt and a medal," p2, "goody bags, just a bottle, token etc. vouchers," p3 (Appendix III).

Furthermore, according to the event, organisers have used different strategies to differentiate their sport event, most of them mainly used atmosphere and core product for this, for example, when asked "how is your event different from other events", participant 1 stated, "the idea of the costumes, dressing up to the themes", "it is the colour aspect that makes it... a bit different, p2", "it'll be a fun event... not many people have done dragon boating before, $p 3$ " and "fun event... different fancy dresses, $p 5$ " (Appendix III). However, only one manager used location (facility) as the main different point of his sport event, "facilities here at Northumbria are like one of the best in north east... a chance to use the facilities, really really good facilities, like thousands of pounds, like millions of pounds" (Appendix III).

The event organisers have used different selling points to differentiate their sport event, through which they try to create a different experience for the customers. Event organisers' differentiation strategies differ depending to their target audience. However according to this study most of the event managers have tried to differentiate their event through the atmosphere and core product. Although the event organiser should do some proper market research before selecting the unique selling points for differentiating an event.

\section{Discussion}

The results of this study suggest that different age groups do not perceive the importance of atmosphere differently. Reference to the Biscaia et al. [26] reveals that the event atmosphere is a fundamental factor for the customers to make a decision on attending an event, however, that decision does not affect their gender or age. Turning to the qualitative data analysis, it was 
found that most of the event managers planned to differentiate their event from other events through the atmosphere and core product. For instance, participant 2 stated that "the idea of the costumes, dressing up to the themes", "it is the colour aspect that makes it... a bit different", "it'll be a fun event... and "fun event... different fancy dress, $p 5$ " (Appendix III).

In addition, findings reveal in this study, that the event profile is more important when spectators are deciding whether to attend an event rather than facility. This finding is also supported by the results from Lee 1990 and Neirtti et al. [1] study suggesting that the event profile (sport legend, global dimension, attraction of event, scale of event) is one of the major influencing factors for consumers to attend an event and also once-in-a-lifetime opportunity affects a fan's decision to attend an event. It means that people like to participate in the most popular, most competitive and world class sport events because sport spectators like to consume rare opportunities. Also, a world class sport event would be held in world standard sport facilities. Therefore spectators are not that concerned about facilities when deciding to attend a world class event.

Furthermore, the present study found out that there is a positive co-relation between core product and facility; therefore core product and facility have positively influenced people's decision of attending a sport event. A study by Theodorakis et al. [35] found that a quality sport facility environment contains elements such as aesthetics, accessibility, security, space/ function, and the employees have a direct link with spectator attendance at sport events. Supported to above findings of Theodorakis et al. [35] present study found out that one of the sport event managers used the facility as his event's major differentiation factor, that event manager hopes to provide an internationally standard facility for their target market, through which they expect to provide a different experience for them. For instance, participant 4 stated that "chance to like use the facilities, like really good facilities, like thousands of pounds, like millions of pounds" (Appendix III). In addition, the opinion of Koo et al. [31] is that providing a product of quality would lead to customer satisfaction, customer retention, and recommendation for other people to take part and influence to attend future event.

In summary, spectators have different reasons for attending a sport event. Previous studies reveal various factors that have affected spectators to attend a sport event and also the present study found factors affecting sport event consumption; those factors mention that early part of this study as well as understand what unique selling points event managers used for differentiate their event. After the analysing previous studies and present study findings, in managerial perspective managers tried to differentiate their product according to their target market as well as consumers' perspective they are perceived every factors as important for get decision on attend sport event. Therefore, event managers should do market research and need to be concern consumers' needs and wants before selecting unique selling points for their event [36].

\section{Limitations}

The present study of investigating factors that influence the customer's decision making process to attend a sport event and the product differentiation strategies employed by Event Organizers had several limitations. The sample size of the interviews section is significantly small. A small sample size directly affects the findings of this study; therefore the inability of collecting data from a sufficient sample had led to the problem of generalization of the findings [48-54]. In addition, the quantitative data collecting part was limited to the Likertscale measuring method and the present study was limited to six factors that influence the customer's attendance at a sport event. The qualitative part of this study has interviewed students who have planned to conduct an event as their assignment which could also affect the findings as it does not provide clear perception of the event manager due to the lack of practical experience.

In conclusion, the findings of the present study is not generalized according to the sample, therefore another researcher can conduct a similar research using different samples and by using event managers who are working in the sports sector. Furthermore, this study used six factors for measuring customer perception of attending an event; therefore researchers suggest that future studies could be done using different factors that influence the sport spectators' decision on attending a sport event.

\section{References}

1. Spence M (1976) Product differentiation and welfare. The American Economic Review 27(1): 407-414.

2. Hall J, O Mahony B, Vieceli J (2010) An empirical model of attendance factors at major sporting events. International Journal of Hospitality Management 29(2): 328-334.

3. Edwards W, Barron FH (1994) SMARTS and SMARTER: Improved simple methods for multi attribute utility measurement. Organizational behavior and human decision processes 60(3): 306-325.

4. Keller KL (1993) Conceptualizing, measuring, and managing customerbased brand equity. The Journal of Marketing 57(1): 1-22.

5. Steckler A, Mc Leroy KR, Goodman RM, Bird ST, Mc Cormick L (1992) Toward integrating qualitative and quantitative methods: an introduction. Health education quarterly 19(1): 1-8.

6. Filo K, Funk DC, O Brien D (2009) The meaning behind attachment: Exploring camaraderie, cause, and competency at a charity sport event. Journal of Sport Management 23(3): 361-387.

7. Alpert MI (1971) Identification of determinant attributes: A comparison of methods. Journal of Marketing Research 8(2): 184-191.

8. Dickson PR, Ginter JL (1987) Market segmentation, product differentiation, and marketing strategy. The Journal of Marketing 51(2): 1-10.

9. Yoshida M, James JD (2010) Customer satisfaction with game and service experiences: Antecedents and consequences. Journal of sport management 24(3): 338-361. 
10. Pan DW, Baker JA (1999) Mapping of intercollegiate sports relative to selected attributes as determined by a product differentiation strategy. Journal of sport behavior 22(1): 69.

11. Schofield JA (1983) Performance and attendance at professional team sports. Journal of Sport Behaviour 6(4): 196-206.

12. Carmichael F, Millington J, Simmons R (1999) Elasticity of demand for rugby league attendance and the impact of Bsky B. Applied Economics Letters 6(12): 797-800.

13. Baade RA, Tiehen LJ (1990) An analysis of major league baseball attendance, 1969-1987. Journal of Sport \& Social Issues 14(1): 14-32.

14. Li X, Petrick JF (2010) Towards an integrative model of loyalty formation: The role of quality and value. Leisure Sciences 32(3): 201221.

15. Wong A (2004) The role of emotional satisfaction in service encounters. Managing Service Quality: An International Journal 14(5): 365-376.

16. Branvold SE, Pan DW, Gabert TE (1997) Effects of winning percentage and market size on attendance in minor league baseball. Sport Marketing Quarterly 6(4): 35-42.

17. Theodorakis ND, Alexandris K, Tsigilis N, Karvounis S (2013) Predicting spectators' behavioural intentions in professional football: The role of satisfaction and service quality. Sport Management Review 16(1): 8596.

18. Kleinc SS, Baker SM (2004) An integrative review of material possession attachment. Academy or Marketing Science Review 1(1): 1-29.

19. Kleine SS, Kleine III RE, Allen CT (1995) How is a possession "me" or "not me"? Characterizing types and an antecedent of material possession attachment. Journal of Consumer Research 22(3): 327-343.

20. Kyle G, Graefe A, Manning R, Bacon J (2004) Effect of activity involvement and place attachment on recreationists' perceptions of setting density. Journal of Leisure Research 36(2): 209-231.

21. Funk DC, Ridinger LL, Moorman AM (2003) Understanding consumer support: Extending the Sport Interest Inventory (SII) to examine individual differences among women's professional sport consumers. Sport Management Review 6(1): 1-31.

22. Bansal HS, Irving PG, Taylor SF (2004) A three-component model of customer to service providers. Journal of the Academy of marketing Science 32(3): 234-250.

23. Moutinho L (1987) Consumer behavior in tourism. European journal of marketing 21(10): 5-44.

24. Matsuoka H, Chelladurai P, Harada M (2003) Direct and interaction effects of team identification and satisfaction on intention to attend games. Sport Marketing Quarterly 12(4): 244-253.

25. Madrigal R (2003) Investigating an evolving leisure experience: Antecedents and consequences of spectator affect during a live sporting event. Journal of Leisure Research 35(1): 23.

26. Biscaia R, Correia A, Rosado A, Maroco J, Ross S (2012) The effects of emotions on football spectators' satisfaction and behavioral intentions. European Sport Management Quarterly 12(3): 227-242.

27. Cronin JJ, Taylor SA (1992) Measuring service quality: A re-examination and extension. Journal of Marketing 56(3): 56-68.

28. Madrigal R (1995) Cognitive and affective determinants of fan satisfaction with sporting event attendance. Journal of leisure research 27(3): 205.

29. Tsuji Y, Bennett G, Zhang J (2007) Consumer satisfaction with an action sports event. Sport Marketing Quarterly 16(4): 199-208.

30. Seiders K, Voss GB, Grewal D, Godfrey AL (2005) Do satisfied customers buy more? Examining moderating influences in a retailing context. Journal of Marketing 69(4): 26-43.
31. Koo GY, Hardin R, Mc Clung S, Jung T, Cronin J, et al. (2009) Examination of the causal effects between the dimensions of service quality and spectator satisfaction in minor league baseball. International journal of sports marketing \& sponsorship 11(1): 46.

32. Clemes MD, Brush GJ, Collins MJ (2011) Analysing the professional sport experience: A hierarchical approach. Sport Management Review 14(4): 370-388.

33. Kuenzel S, Yassim M (2007) The effect of joy on the behaviour of cricket spectators: The mediating role of satisfaction. Managing Leisure 12(1): 43-57.

34. Wakefield KL, Blodgett JG (1996) The effect of the services cape on customers' behavioral intentions in leisure service settings. Journal of Services Marketing 10(6): 45-61.

35. Theodorakis N, Kambitsis C, Laios A (2001) Relationship between measures of service quality and satisfaction of spectators in professional sports. Managing Service Quality: An International Journal 11(6): 431-438.

36. Ferreira M, Armstrong KL (2004) An exploratory examination of attributes influencing students' decisions to attend college sport events. Sport Marketing Quarterly 13(4): 194-208.

37. Oliver RL, Rust RT, Varki S (1997) Customer delight: Foundations, findings, and managerial insight. Journal of Retailing 73(3): 311-336.

38. Otnes C, Lowrey TM, Shrum LJ (1997) Toward an understanding of consumer ambivalence. Journal of Consumer Research 24(1): 80-93.

39. Bodet G, Bernache Assollant I (2011) Consumer loyalty in sport spectatorship services: The relationships with consumer satisfaction and team identification. Psychology \& Marketing 28(8): 781-802.

40. Speed R, Thompson P (2000) Determinants of sports sponsorship response. Journal of the Academy of Marketing Science 28(2): 226238.

41. Arnould EJ, Price LL (1993) River magic: Extraordinary experience and the extended service encounter. Journal of consumer Research 20(1): 24-45.

42. Kyle GT, Mowen AJ, Absher JD, Havitz ME (2006) Commitment to public leisure service providers: A conceptual and psychometric analysis. Journal of Leisure Research 38(1): 78.

43. Kaynak E, Salman GG, Tatoglu E (2008) An integrative framework linking brand associations and brand loyalty in professional sports. Journal of Brand Management 15(5): 336-357.

44. Neirotti LD, Bosetti HA, Teed KC (2001) Motivation to attend the 1996 summer Olympic Games. Journal of Travel Research 39(3): 327-331.

45. Greenwell TC, Fink JS, Pastore DL (2002) Assessing the influence of the physical sports facility on customer satisfaction within the context of the service experience. Sport Management Review 5(2): 129-148.

46. Laverie DA, Arnett DB (2000) Factors affecting fan attendance: The influence of identity salience and satisfaction. Journal of leisure Research 32(2): 225.

47. Mahony DF, Madrigal R, Howard D (2000) Using the psychological commitment to team (PCT) scale to segment sport consumers based on loyalty. Sport Marketing Quarterly 9(1): 15-25.

48. Carr LT (1994) The strengths and weaknesses of quantitative and qualitative research: What method for nursing? Journal of advanced nursing 20(4): 716-721.

49. Bassett C, Bassett J (2003) Quantitative and qualitative research. The Journal of Perioperative Practice 13(3): 116.

50. Clemes MD, Brush GJ, Collins MJ (2011) Analysing the professional sport experience: A hierarchical approach. Sport Management Review 14(4): 370-388. 
51. Johnson RB, Onwuegbuzie AJ (2004) Mixed methods research: A research paradigm whose time has come. Educational researcher 33(7): 14-26.

52. Smith WR (1995) Product differentiation and market segmentation as alternative marketing strategies. Marketing Management 4(3): 63
53. Sumino M, Harada M (2004) Affective experience of J League fans: the relationship between affective experience, team loyalty and intention to attend. Managing Leisure 9(4): 181-192.

54. Wann DL, Bayens C, Driver A (2004) Likelihood of attending a sporting event as a function of ticket scarcity and team identification. Sport marketing quarterly 13(4): 209-215.

\section{Your next submission with Juniper Publishers}

will reach you the below assets

- Quality Editorial service

- Swift Peer Review

- Reprints availability

- E-prints Service

- Manuscript Podcast for convenient understanding

- Global attainment for your research

- Manuscript accessibility in different formats

( Pdf, E-pub, Full Text, Audio)

- Unceasing customer service

Track the below URL for one-step submission https://juniperpublishers.com/online-submission.php 